\title{
RISET DI BAWAH KEMENRISTEK-DIKTI (PROSPEK DAN TANTANGAN)
}

\author{
* Yudi Hartono
}

\begin{abstract}
Abstrak
Dipisahkannya Kemendikbud mengandung prospek dan tantangan. Di bawah payung Kemenristek-Dikti, perguruan tinggi lebih memiliki peluang untuk menghasilkan inovasi melalui riset lebih serius yang dapat menjadi terobosan inovatif dalam iptek. PT perlu mengembangkan diri dari "PT pengajaran (teaching university)" menjadi PT berbasis riset (research-based university). Sementara itu, Kementerian Kebudayaan dan Pendidikan Dasar dan Menengah juga bisa lebih fokus untuk menyiapkan peserta didik ke jenjang yang lebih tinggi tanpa dibebani lagi dengan urusan pendidikan tinggi. Tantangannya adalah sinergi dengan lembaga-lembaga riset seperti LIPI, Lapan, BPPT. Kemauan politik dari pemerintah untuk menggunakan hasil riset yang dihasilkan lembaga-lembaga penelitian juga perlu didorong. Tantangan lain adalah rendahnya alokasi dana riset, kurangnya kebebasan menjalankan otonomi kampus dan mimbar akademik, serta posisi pendidikan tinggi keagamaan. Tidak kalah penting adalah tantangan bagi LPTK dalam menjalin sinergi dengan Kementerian Kebudayaan dan Pendidikan Dasar dan Menengah dalam program-program praktek pendidikan.
\end{abstract}

\section{Kata kunci: riset, kemenristek-dikti}

\section{Pendahuluan}

Pemerintahan Presiden Joko

Widodo dan Wakil Presiden Jusuf Kalla memisahkan Kementerian Pendidikan dan Kebudayaan menjadi dua, yaitu Kementerian Kebudayaan dan Pendidikan Dasar dan Menengah, dan Kementerian Riset Teknologi dan Pendidikan Tinggi.

Presiden Joko Widodo mengungkapkan alasan penggabungan kementerian pendidikan tinggi dan ristek bahwa ke depan riset atau penelitian yang berhubungan dengan teknologi, riset sosial dan riset pertanian, dan yang berkaitan dengan maritim bisa diaplikasikan oleh masyarakat. Pemerintahan Jokowi-JK melihat problem utama penelitian yang ada saat ini dinilai tidak terakomodasi dengan baik sehingga manfaat hasil penelitian tidak dapat dirasakan oleh masyarakat. Riset selama ini tidak terkonsolidasi dengan baik. Anggaran ada di manamana, tetapi hasilnya tidak kelihatan. Sebagai contoh tidak diaplikasikannya hasil penelitian yang dilakukan Kementrian Pertanian tampak pada hasil padi di Indonesia sehingga tidak bisa swasembada.

Sebelumnya, wacana pemisahan Kementerian Pendidikan dan Kebudayaan sempat menimbulkan pro dan kontra. Sejumlah pakar pendidikan yang tergabung dalam Education Forum (EF) menolak pemisahan Direktorat 
Jenderal Pendidikan Tinggi (Dikti) dari Kementerian Pendidikan dan Kebudayaan. Rencana pemisahan Kemdikbud dinilai tidak memiliki dasar argumen yang kuat.

Menurut peneliti pendidikan dari Kementerian Perencanaan Pembangunan Nasional/Bappenas, Amich Alhumami, minimnya jumlah riset di Indonesia justru disebabkan karena tidak adanya infrastruktur untuk pengembangan ilmu pengetahuan dan teknologi. Fasilitas riset seperti ketersediaan laboratorium untuk dosen dinilainya masih sangat minim. Sementara itu, HAR Tilaar, Guru Besar Emeritus Universitas Negeri Jakarta, mengatakan pendidikan tidak bisa dilepaskan dari kebudayaan. Pendidikan juga berarti satu kesatuan utuh mulai dari dasar, menengah, dan tinggi. Perguruan tinggi tidak lepas dari pembentukan karakter Indonesia berdasarkan kebudayaan nasional, sebab karakter berarti pengembangan nilainilai kebudayaan. ${ }^{1}$

Menurut Daoed Joesoef, mantan Mendikbud, perguruan tinggi memang menangani riset, tetapi tujuan esensialnya bukanlah menghasilkan sesuatu yang "siap pakai" di bidang kehidupan apapun, melainkan membuat manusia berspirit ilmiah karena spirit inilah yang menggerakkan manusia

1Dalam Suara Pembaruan, Sabtu 20 September 2014. untuk terus berusaha menyempurnakan pengorganisasian pengetahuan begitu rupa hingga menguasai semakin banyak potensi tersembunyi dalam alam dan pergaulan (interaksi) manusia. Tanpa spirit tersebut orang tidak akan menjadi periset, sementara riset diperlukan demi perbaikan serta kemajuan hidup dan kehidupan, Rekomendasi Forum Rektor Indonesia (FRI) agar perguruan tinggi ditempatkan dalam yurisdiksi Kementerian Riset dan Teknologi menunjukkan ada kesalahpahaman tentang misi pendidikan keilmuan dari PT. ${ }^{2}$

Sementara itu, Arif Rahman, Guru Besar Universitas Negeri Jakarta, tidak mempersoalkan rencana Presiden Joko Widodo memecah Kementerian Pendidikan dan Kebudayaan dalam kabinet pemerintahannya. Dulu antara pendidikan dasar dan menengah dengan pendidikan tinggi juga pernah dipisah pengelolaannya. Sementara kebudayaan, bisa masuk ke semua bidang. Ia hanya menekankan agar program-program mengenai pendidikan tidak boleh diabaikan. Tri Dharma perguruan tinggi harus kuat. Pendidikan dasar dan

\footnotetext{
2Daoed Joesoef, "Misi Perguruan Tinggi Kita" dalam KOMPAS, Edisi 18 Februari 2014.
} 
menengah meletakkan dasar pendidikan ke tingkat lebih tinggi. ${ }^{3}$

Ketua Umum Asosiasi Perguruan Tinggi Swasta Indonesia (Aptisi) Edy Suandi Hamid mengapresiasi langkah Presiden Joko Widodo memisahkan Kementerian Pendidikan Dasar dan Menengah (Dikdasmen) dengan Kementerian Riset, Teknologi, dan Pendidikan Tinggi (Dikti). Dengan pemisahan itu diharapkan pengelolaan lebih fokus dan terarah, sehingga bisa lebih memperbaiki pendidikan di tanah air, baik pendidikan dasar dan menengah (dikdasmen) maupun pendidikan tinggi (dikti). Menurutnya, lingkup pendidikan yang terlalu luas dan cakupan wilayah yang sangat besar membuat Kementerian Pendidikan dan Kebudayaan (Kemdikbud) kedodoran dalam menangani pendidikan. ${ }^{4}$

Sejumlah peneliti juga menyambut baik rencana pemerintah Jokowi-Kalla yang akan memisahkan kementerian pendidikan menjadi dua bagian. Peneliti dari Pusat Peneliti Politik (P2P) LIPI, Riefqi Muna mengatakan bahwa rencana ini akan memberikan keleluasaan bagi riset di Indonesia dan otomatis meningkatkan anggaran meski dasarnya

${ }^{3}$ Tokoh Pendidikan Tak Persoalkan Pemisahan Kemdikbud, Dalam http://www.jpnn.com, Jumat, 24 Oktober 2014, diakses 24 November 2014.

4http://www.solopos.com/2014/10/27/dia kses 24 November 2014. tidak tahu betul rencana di baliknya. Permasalahan yang dialami riset di Indonesia saat ini adalah kurangnya komitmen pemerintah untuk mendukung penelitian dari tahun ke tahun. Komitmen negara untuk menudukung riset mengalami penurunan secara sistematis dan terstruktur dari tahun 1969 hingga 2000, terlihat dari komposisi anggaran yang sangat kecil, yakni tidak sampai satu persen dari APBN setiap tahunnya. Peneliti Universitas Mulawarman, Samarinda, Kalimantan Timur, Aji Sofyan Effendi juga menyambut baik, dan berharap pemerintah yang baru bisa lebih fokus memperhatikan peneliti Indonesia. Pemisahan diharapkan pemerintah akan fokus dan peduli dalam mendorong penelitian di Indonesia. Peneliti lain dari LIPI, Syamsuddin Haris, mengatakan, pemisahan akan membuat kementerian lebih fokus dan efektivitas akan tercapai. Pemisahan yang dilakukan oleh pemerintah Jokowi-Kalla merupakan masukan dari berbagai kalangan, termasuk LIPI setelah melihat kinerja pendidikan nasional selama ini. ${ }^{5}$ Tentu saja pro dan kontra tersebut segera

5

http://m.jurnas.com/news/149517/Pen eliti-Sambut-Baik-Rencana-PemisahanKemendikbud---2014/1/SosialBudaya/Pendidikan/diakes 26 $\mathrm{N} \backslash$ ovember 2014. 
berakhir setelah Presiden Joko Widodo mengumumkan kabinetnya. Bagaimana prospek dan tantangan ke depan setelah pemisahan Kemendikbud?

\section{Perspektif Historis Kemdikbud}

Sejak kemerdekaan, Indonesia sudah mengalami pengalaman panjang kementerian pendidikan. Kementerian pendidikan pertama bernama Kementerian Pengajaran. Organisasinya masih sangat sederhana, tetapi kesadaran untuk menyiapkan kurikulum sudah dilakukan. Menteri Pengajaran yang pertama dalam sejarah Republik Indonesia adalah Ki Hadjar Dewantara.

Pada Kabinet Syahrir I, Menteri Pengajaran dipercayakan kepada Mr. Mulia. Mr. Mulia melakukan berbagai langkah seperti meneruskan kebijakan menteri sebelumnya di bidang kurikulum berwawasan kebangsaan, memperbaiki sarana dan prasarana pendidikan, serta menambah jumlah pengajar.

Pada Kabinet Syahrir II, Menteri Pengajaran dijabat Muhammad Sjafei sampai tanggal 2 Oktober 1946. Selanjutnya Menteri Pengajaran dipercayakan kepada Mr. Soewandi hingga 27 Juni 1947. Pada era kepemimpinan Mr. Soewandi ini terbentuk Panitia Penyelidik Pengajaran Republik Indonesia yang diketuai $\mathrm{Ki}$ Hadjar Dewantara. Panitia ini bertujuan meletakkan dasar-dasar dan susunan pengajaran baru.
Pada Era Demokrasi Liberal (19511959) stabilitas politik menjadi sesuatu yang langka, demikian halnya dengan program yang bisa dijadikan tonggak, tidak bisa dideskripsikan dengan baik. Selama masa demokrasi liberal, sekitar sembilan tahun, telah terjadi tujuh kali pergantian kabinet. Kabinet Natsir yang terbentuk tanggal 6 September 1950, menunjuk Dr. Bahder Johan sebagai Menteri Pengajaran Pendidikan dan Kebudayaan (PP dan K). Mulai bulan April 1951 Kabinet Natsir digantikan Kabinet Sukiman yang menunjuk Mr. Wongsonegoro sebagai Menteri PP dan K. Selanjutnya Dr. Bahder Johan menjabat Menteri PP dan K sekali lagi, kemudian digantikan Mr. Mohammad Yamin, RM. Soewandi, Ki Sarino Mangunpranoto, dan Prof. Dr. Prijono. Pada periode ini, kebijakan pendidikan merupakan kelanjutan kebijakan menteri periode sebelumnya. Yang menonjol pada era ini adalah lahirnya payung hukum legal formal di bidang pendidikan yaitu UU Pokok Pendidikan Nomor 4 Tahun 1950.

Dekrit Presiden 5 Juli 1959 mengakhiri era demokrasi parlementer digantikan era demokrasi terpimpin (1959-1966). Di era demokrasi terpimpin banyak ujian yang menimpa bangsa Indonesia. Konfrontasi dengan Belanda dalam masalah Irian Barat, 
sampai peristiwa G30S/PKI menjadi ujian berat bagi bangsa Indonesia.

Dalam Kabinet Kerja I, 10 Juli 1959 - 18 Februari 1960, status kementerian diubah menjadi menteri muda. Kementerian yang mengurusi pendidikan dibagi menjadi tiga menteri muda. Menteri Muda Bidang Sosial Kulturil dipegang Dr. Prijono, Menteri Muda PP dan $\mathrm{K}$ dipegang Sudibjo, dan Menteri Muda Urusan Pengerahan Tenaga Rakyat dipegang Sujono. Pada periode 27 Agustus 1964 - 21 Febuari 1966 masa Kabinet Dwikora terdapat Departemen Pendidikan Dasar dan Kebudayaan dan Departemen Perguruan Tinggi dan Ilmu Pengetahuan dengan pejabat menterinya Letjen TNI Dr. Teuku Syarif Thayeb.

Setelah Pemberontakan G30S/PKI berhasil dipadamkan, terjadilah peralihan dari demokrasi terpimpin ke demokrasi Pancasila. Era tersebut dikenal dengan nama Orde Baru yang dipimpin Presiden Soeharto. Kebijakan di bidang pendidikan di era Orde Baru cukup banyak dan beragam mengingat orde ini memegang kekuasaan cukup lama yaitu 32 tahun. Kebijakan-kebijakan tersebut antara lain kewajiban penataran P4 bagi peserta didik, normalisasi kehidupan kampus, bina siswa melalui OSIS, ejaan Bahasa Indonesia yang disempurnakan atau EYD, kuliah kerja nyata (KKN) bagi mahasiswa, merintis sekolah pembangunan, dan lain-lain.
Pada era ini tepatnya tahun 1978 tahun ajaran baru digeser ke bulan Juni. Pembangunan infrastruktur pendidikan juga berkembang pesat pada era Orde Baru tersebut. Menteri pendidikan dan kebudayaan di era Orde Baru antara lain Dr. Daud Joesoef, Prof. Dr. Nugroho Notosusanto, Prof. Dr. Faud Hassan, Prof. Dr. Ing. Wardiman Djojonegoro, dan Prof. Dr. Wiranto Aris Munandar.

Pada tahun 1998 Indonesia diterpa krisis politik dan ekonomi. Demonstrasi besar-besaran di tahun tersebut berhasil memaksa Presiden Soeharto meletakkan jabatannya. Kabinet pertama di era reformasi adalah kabinet hasil Pemilu 1999 yang dipimpin Presiden Abdurrahman Wahid. Pada masa ini Departemen Pendidikan dan Kebudayaan diubah menjadi Departemen Pendidikan Nasional dengan menunjuk Dr. Yahya Muhaimin sebagai Menteri Pendidikan Nasional. Pada tahun 2001 MPR menurunkan Presiden Abdurrahman Wahid dalam sidang istimewa MPR dan mengangkat Megawati Soekarnoputri sebagai presiden. Di era pemerintahan Presiden Megawati, Mendiknas dijabat Prof. Drs. A. Malik Fadjar, M.Sc.

Pemilihan Umum 2004 dan 2009 rakyat Indonesia memilih presiden secara langsung. Pada dua pemilu tersebut Susilo Bambang Yudhoyono berhasil terpilih menjadi presiden. 
Selama kepemimpinan Presiden Susilo Bambang Yudhoyono, Mendiknas dijabat Prof. Dr. Bambang Sudibyo, MBA. Dan Prof. Dr. Ir. Mohammad Nuh. Pada tahun 2011 istilah departemen diganti menjadi kementerian dan pada tahun 2012 bidang pendidikan dan kebudayaan disatukan kembali menjadi Kementerian Pendidikan dan Kebudayaan. Dan saat ini menjadi Kementerian Kebudayaan dan Pendidikan Dasar dan Menengah Kementerian Riset dan Teknologi dan Pendidikan Tinggi.

Sejak kemerdekaan 17 Agustus 1945 kementerian pendidikan Indonesia mengalami berbagai perubahan nama sebagai berikut.

\begin{tabular}{|c|c|c|}
\hline No & $\begin{array}{c}\text { Nama } \\
\text { Kementrian }\end{array}$ & Periode \\
\hline 1 & $\begin{array}{l}\text { Kementerian } \\
\text { Pengajaran }\end{array}$ & $\begin{array}{lr}19 & \text { Agustus } \\
1945- & 29 \\
\text { September } & \\
1948 & \end{array}$ \\
\hline 2 & $\begin{array}{l}\text { Kementrian } \\
\text { Pendidikan, } \\
\text { Pengajaran dan } \\
\text { Kebudayaan }\end{array}$ & $\begin{array}{l}29 \text { September } \\
1948-10 \\
\text { Agustus } 1957\end{array}$ \\
\hline 3 & $\begin{array}{l}\text { Departemen } \\
\text { Pendidikan, } \\
\text { Pengajaran dan } \\
\text { Kebudayaan }\end{array}$ & $\begin{array}{lr}10 & \text { Agustus } \\
1957-6 & \text { Maret } \\
1962 & \end{array}$ \\
\hline 4 & $\begin{array}{l}\text { Departemen } \\
\text { Pendidikan } \\
\text { Dasar dan } \\
\text { Kebudayaan dan } \\
\text { Departemen } \\
\text { Perguruan } \\
\text { Tinggi dan Ilmu } \\
\text { Pengetahuan } \\
\end{array}$ & $\begin{array}{l}6 \text { Maret } 1962- \\
27 \text { Maret } 1966\end{array}$ \\
\hline 5 & $\begin{array}{l}\text { Departemen } \\
\text { Pendidikan dan } \\
\text { Kebudayaan }\end{array}$ & $\begin{array}{l}25 \text { Juli 1966-26 } \\
\text { Oktober } 1999\end{array}$ \\
\hline 6 & Departemen & Oktober \\
\hline
\end{tabular}

\begin{tabular}{|c|c|c|}
\hline & $\begin{array}{l}\text { Pendidikan } \\
\text { Nasional }\end{array}$ & $\begin{array}{l}\text { 1999-27 } \\
\text { Oktober } 2014\end{array}$ \\
\hline 7 & $\begin{array}{l}\text { Kementerian } \\
\text { Kebudayaan dan } \\
\text { Pendidikan } \\
\text { Dasar dan } \\
\text { Menengah } \\
\text { Kementerian } \\
\text { Riset dan } \\
\text { Teknologi dan } \\
\text { Pendidikan } \\
\text { Tinggi }\end{array}$ & $\begin{array}{lr}27 & \text { Oktober } \\
2014 & \text {-sekarang }\end{array}$ \\
\hline
\end{tabular}

\section{Pembelajaran dari Negara Lain}

Di Malaysia, terdapat dua kementerian, yaitu Kementerian Pelajaran Malaysia (KPM) dan Kementerian Pengajian Tinggi Malaysia (KPTM). Kementerian yang pertama berfokus ke pendidikan dasar dan menengah, sedangkan kementerian kedua pendidikan tinggi. Bidang pendidikan tinggi di Malaysia diurus kementerian yang memiliki anggaran memadai untuk riset dan publikasi internasional. Hasilnya, sejumlah universitas di Malaysia menduduki posisi terpenting dalam sejumlah survei publikasi internasional. Cukup banyak putra-putri Indonesia yang melanjutkan studi lanjut (S-2/S-3) ke Malaysia, salah satu alasannya karena bidang risetnya setara dengan negara maju. ${ }^{6}$

Belajar dari dari KPTM, menurut Sudaryanto (2014), Kementerian

6Sudaryanto, "Quo Vadis Kementerian Dikti?" dalam Republika, Edisi Rabu, 16 September 2014. 
Pendidikan Tinggi dan Riset perlu diberi kewenangan dan anggaran memadai guna meningkatkan kualitas perguruan tinggi. Para dosennya juga aktif didorong untuk melakukan riset dan publikasi internasional bersama dosen universitas di luar negeri. Bahkan, jika perlu profesor dari luar negeri ditarik menjadi pengajar tamu di PT di Indonesia.

Kementerian Pendidikan Tinggi dan Riset perlu melakukan pengelompokan PT di Tanah Air. Tahun 2007, Dikti telah merilis 50 Promising Indonesian Universities. Melalui rilis tersebut, Dikti mengelompokkan 50 universitas di Indonesia yang terkategorikan "terbaik". Bagi kalangan PTS, rilis 50 Promising Indonesian Universities tidak berpengaruh apa-apa mengingat Dikti tidak memiliki ikhtiar yang memadai setelahnya. Untuk hal ini, perlu belajar dari Cina. Pada 1998, Biro Pelayanan Pendidikan Rakyat Cina mendanai 39 universitas melalui "Proyek 985". Dari program tersebut, akhirnya Peking University dan Tsinghua University berhasil menjadi universitas kelas dunia, dan sejumlah universitas di Cina banyak diincar mahasiswa luar negeri, termasuk dari Indonesia, guna menempuh studi S-1, S2, dan S-3. Selanjutnya, melalui "Proyek 211" Pemerintah Cina kembali membangun sekitar 100 universitas utama (key university) dan 1.000 disiplin ilmu utama (key diciplines) dari 1.700 universitas yang ada. Ini menjadi kunci keberhasilan PT di Cina yang patut dijadikan bahan pembelajaran. ${ }^{7}$

\section{Prospek dan Tantangan}

Menurut catatan Azyumardi Azra (2014) gagasan dan wacana tentang perlunya pembentukan kementerian khusus yang menangani pendidikan tinggi sesungguhnya tidaklah baru. Wakil Presiden Jusuf Kalla pada 2008-2009 pernah mengumpulkan berbagai pihak untuk membahas dan merumuskan pembentukan Kementerian Pendidikan Tinggi dan Ilmu Pengetahuan dan Teknologi (KPT-Iptek). Hasilnya adalah naskah akademis tentang pembentukan kementerian ini bagi pemerintahan pasca Pemilu 2009. Namun, karena Jusuf Kalla tidak berhasil menang dalam Pilpres 2009, rencana pembentukan KPT-Iptek tidak terlaksana. ${ }^{8}$

Banyak alasan kuat mendasari pembentukan kementerian ini, seperti terlalu besarnya Kemdikbud yang menangani pendidikan dasar, menengah, dan tinggi sehingga keberatan beban dan tidak fokus. Selain itu, berada di bawah Kemdikbud, pendidikan tinggi kian terlihat mengalami resentralisasi.

${ }^{7}$ Ibid.

${ }^{8}$ Azyumardi Azra, "Kontroversi KemendiktiRistek" dalam KOMPAS, Edisi Rabu 26 Februari 2014. 
Kemudian muncul pandangan dari banyak kalangan bahwa perguruan tinggi negeri kini cenderung hanya menjadi unit pelaksana teknis Kemdikbud. Dengan pemisahan pendidikan tinggi menjadi kementerian sendiri, perguruan tinggi diharapkan bisa lebih mengembangkan otonominya. Dengan begitu, menjadi lebih mungkin bagi PT untuk memaksimalkan pencapaiannya. Tidak hanya dalam bidang pendidikan, tetapi juga penelitian dan pengabdian masyarakat.

Selain itu, perguruan tinggi, khususnya negeri, memiliki sumber daya manusia relatif lebih banyak dan berkualitas tidak hanya untuk pengajaran, tetapi juga dalam penelitian. Berbagai survei dan data menunjukkan, sejumlah PT papan atas Indonesia menghasilkan banyak penelitian inovatif yang dikutip secara internasional dibandingkan dengan lembaga khusus untuk riset dan pengembangan iptek seperti LIPI dan BPPT. Namun, karena dana penelitian relatif sangat minim, PT tidak dapat memaksimalkan kapasitas penelitiannya untuk pengembangan iptek.

Kegiatan riset di Indonesia terpencar-pencar pada berbagai lembaga dan instansi, seperti Kemenristek, LIPI, dan BPPT. Institusi-institusi ini bergerak sendiri-sendiri tanpa koordinasi sehingga tidak mampu mencapai hasil maksimal dalam memajukan iptek. Menurut Forum Rektor Indonesia (FRI), riset-riset yang dilakukan perguruan tinggi tidak bersinergi dengan lembaga riset lainnya. Selain ini perguruan tinggi juga dianggap tidak fokus mengembangkan riset dan teknologi.

Justifikasi lain untuk memisahkan perguruan tinggi dari domain Kemendikbud adalah karena negara lain, seperti Malaysia, Tiongkok, Korea Selatan, dan India, sudah mempraktikkannya. Di Indonesia, semasa pemerintahan Bung Karno pernah ada Kementerian Pendidikan Tinggi dan Ilmu Pengetahuan.

Menurut Azumardi Azra (2014),9 PT di bawah payung Kemendikti-Ristek lebih memiliki peluang untuk menghasilkan inovasi melalui riset lebih serius yang dapat menjadi terobosan inovatif dalam iptek. Karena itu, PT perlu meninjau ulang ketentuan tentang tugas para dosen. Mereka wajib tidak sekadar mengajar, tetapi juga melakukan penelitian. Memang tidak semua dosen memiliki imajinasi, kreativitas, dan kapabilitas untuk melakukan riset yang bermutu. Kebanyakan dosen bahkan cenderung terpaku hanya dalam pemenuhan salah satu misi pokok PT, yaitu transmisi ilmu pengetahuan, pencerdasan, dan pembudayaan para

${ }^{9}$ Azyumardi Azra, op.cit. 
mahasiswa. Tugas ini terutama benar pada tingkat strata $1(\mathrm{~S}-1)$, tetapi mesti tidak demikian pada tingkat S-2 dan S-3. Karena itu, PT perlu mengembangkan diri dari "PT pengajaran (teaching university)" menjadi PT berbasis riset (research-based university). Dalam kerangka ini, perekrutan dan promosi dosen wajib lebih didasarkan pada riset inovatif untuk memajukan iptek daripada sekadar mengajar mahasiswa.

Penelitian yang dilakukan para dosen semestinya bukan sekadar riset rutin untuk kenaikan pangkat dengan dana APBN/DIP/PT terbatas, melainkan juga dengan melibatkan dana melalui kemitraan, baik dengan lembaga dalam negeri maupun internasional. Hasil penelitian juga bukan untuk sekadar pertanggungjawaban administratif keuangan; lebih penting lagi guna disebarluaskan melalui jurnal atau penerbitan lain yang diakui pada tingkat internasional.

Langkah sangat urgen adalah PT berbasis riset memerlukan pengembangan program pascasarjana untuk menjadi pusat pendidikan yang lebih berorientasi pada riset daripada sekadar pengajaran. Program pascasarjana semestinya diberdayakan menjadi "mesin penelitian (engine of research)" PT bersama berbagai lembaga riset otonom di lingkungan PT. Sebuah PT berbasis riset memerlukan sedikitnya
25 persen mahasiswa pascasarjana dari jumlah total mahasiswa PT bersangkutan (S-1, S-2, dan S-3). Peningkatan jumlah mahasiswa program pascasarjana untuk mencapai persentase seperti itu jelas bukan dengan memperbanyak program nonreguler semacam program eksekutif, program akhir pekan, atau program kelas jauh.

Program-program seperti iniyang cenderung lebih berorientasi untung (profit making)—sebaliknya justru mengakibatkan tergradasinya program pascasarjana menjadi tempat memperoleh gelar S-2 dan S-3 secara mudah dan cepat. Padahal, semestinya program pascasarjana menjadi pusat pengkajian lanjutan (center for advanced studies) yang menghasilkan berbagai temuan penelitian inovatif untuk kemajuan iptek.

Tantangan di bidang pendidikan, riset, dan teknologi tidak ringan. Terkait sinergi lembaga riset, sebenarnya menjadi tanggung jawab Kementerian Riset dan Teknologi, yakni dengan mengoordinasikan lembaga pemerintah non kementerian, seperti LIPI, Lapan, BPPT. Faktanya, selama ini Kemenristek gagal mensinergikan lembaga-lembaga tersebut. Kemauan politik dari pemerintah untuk menggunakan hasil riset yang dihasilkan lembaga-lembaga penelitian juga masih minim. Saat ini hasil riset lembaga penelitian masih 
sebatas menjadi seperti benda koleksi perpustakaan dan museum. Tantangan lain yang masih menjadi musuh besar pengembangan riset adalah rendahnya alokasi dana yang tersedia untuk riset yang masih di bawah 1 persen dari Produk Domestik Bruto (PDB). Negaranegara yang dijadikan kiblat untuk membentuk Kementerian Pendidikan Tinggi, seperti Tiongkok dan India, juga memiliki anggaran riset yang berkisar di atas 1,2-2 persen dari PDB.

Menurut Ketua Forum Rektor Indonesia (FRI), Ravik Karsidi (2014), banyak rektor merasa hanya diposisikan sebagai pimpinan satuan kerja (satker), sehingga kurang bebas menjalankan otonomi kampus dan mimbar akademik. Hal ini membuat PT tidak bisa berperan maksimum. PT tidak bisa disamakan dengan SMP atau SMA, karena persamaan PT dan sekolah di bawahnya hanya sama-sama lembaga pendidikan. Sementara PT mempunyai tridarma perguruan tinggi yang mencakup penelitian dan pengabdian masyarakat, dua hal ini tidak dimiliki lembaga pendidikan di bawah PT. ${ }^{10}$

Kemendikbud belum optimal memainkan peranan perguruan tinggi dalam bidang riset. Bahkan, riset-riset di perguruan tinggi terlihat lebih berbasis

10http://dok.joglosemar.co/baca/2014/09/ 18 /forum-rektor-dukung-pemisahankemdikbud.html pada orientasi administratif saja. Padahal, orientasi riset adalah ke arah kemanfaatan dari penelitian tersebut. Jangan sampai orientasi kenaikan pangkat menjadi tujuan riset di perguruan tinggi. Sistem mestinya didesain sedemikian rupa, sehingga kenaikan pangkat adalah efek dari kinerja seseorang.

Tantangan lain setelah hadirnya Kemenristek Dikti adalah mengenai nasib lembaga pemerintahan non kementerian yang sebelumnya berada di bawah koordinasi Kemenristek. Apabila masih menggunakan pola lama, yaitu menempatkan lembaga-lembaga itu sebagai lembaga pemerintahan non kementerian, kehadiran Kemenristek Dikti telah keluar dari spirit mensinergikan lembaga-lembaga riset. Hadirnya Kemenristek Dikti juga harus memperjelas posisi pendidikan tinggi keagamaan. Apakah akan tetap memberikan kewenangan mengatur pendidikan tinggi keagamaan oleh Kementerian Agama atau berada di bawah Kemenristek Dikti. ${ }^{11}$

LPTK juga menghadapi tentangan tersendiri. Selama ini program-program praktek pendidikan di sekolah-sekolah relatif tidak ada hambatan yang berarti karena masih dalam satu kementrian.

\footnotetext{
11Tulus Santoso, "Ristek dan Pendidikan Tinggi", KOMPAS Edisi Selasa, 4 November 2014.
} 
Setelah dipisah, maka menjadi tantangan tersendiri dalam menjalin sinergi dengan Kementerian Kebudayaan dan Pendidikan Dasar dan Menengah.

\section{Penutup}

Dipisahkannya Kemendikbud mengandung prospek dan tantangan. Di bawah payung Kemendikti-Ristek, perguruan tinggi lebih memiliki peluang untuk menghasilkan inovasi melalui riset lebih serius yang dapat menjadi terobosan inovatif dalam iptek. PT perlu mengembangkan diri dari "PT pengajaran (teaching university)" menjadi PT berbasis riset (researchbased university). Sementara itu, Kementerian Kebudayaan dan Pendidikan Dasar dan Menengah juga bisa lebih fokus untuk menyiapkan peserta didik ke jenjang yang lebih tinggi tanpa dibebani lagi dengan urusan pendidikan tinggi.

Tantangannya adalah sinergi dengan lembaga-lembaga riset seperti LIPI, Lapan, BPPT. Kemauan politik dari pemerintah untuk menggunakan hasil riset yang dihasilkan lembaga-lembaga penelitian juga perlu didorong. Tantangan lain adalah rendahnya alokasi dana riset, kurangnya kebebasan menjalankan otonomi kampus dan mimbar akademik, serta posisi pendidikan tinggi keagamaan. Tidak kalah penting adalah tantangan bagi LPTK dalam menjalin sinergi dengan
Kementerian Kebudayaan dan Pendidikan Dasar dan Menengah dalam program-program praktek pendidikan.

\section{Daftar Pustaka}

Azyumardi Azra, "Kontroversi KemendiktiRistek" dalam KOMPAS, Edisi Rabu 26 Februari 2014.

Daoed Joesoef, "Misi Perguruan Tinggi Kita" dalam KOMPAS, Edisi 18 Februari 2014

Sudaryanto, "Quo Vadis Kementerian Dikti?" dalam Republika, Edisi Rabu, 16 September 2014.

Suara Pembaruan, Sabtu 20 September 2014.

Tulus Santoso, "Ristek dan Pendidikan Tinggi", KOMPAS Edisi Selasa, 4 November 2014.

\section{Internet:}

http://www.jpnn.com, Jumat, 24 Oktober 2014, diakses 24 November 2014. http://www.solopos.com/2014/10/27/dia kses 24 November 2014. http://m.jurnas.com/news/149517/Penelit i-Sambut-Baik-Rencana-Pemisahan Kemendikbud-2014/1/SosialBudaya/Pendidikan/ diakes $26 \mathrm{~N} \backslash$ ovember 2014.

http://dok.joglosemar.com/baca/2014/ 09/18/forum-rektor-dukungpemisahan-kemdikbud.html 